
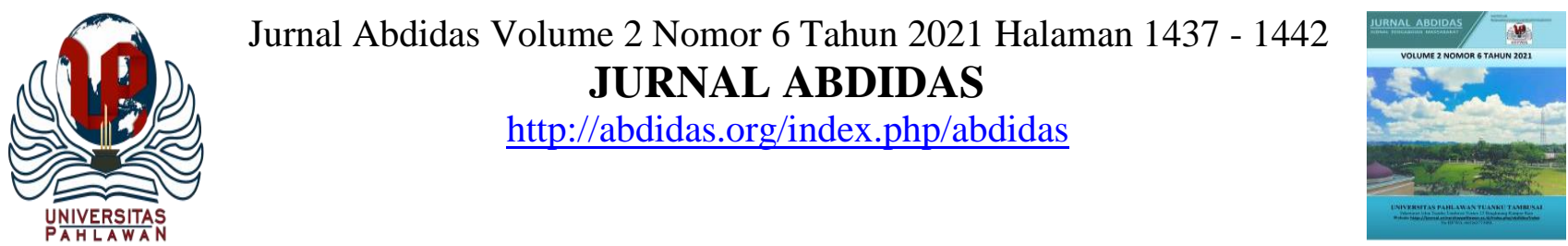

\title{
Sosialisasi Pembuatan dan Aplikasi Pupuk Organik Cair (POC) di Desa Peresak Kecamatan Narmada
}

\author{
Hasan Basri ${ }^{1 \bowtie}$, Meilinda Pahriana Sulastri ${ }^{2}$, Arista Suci Andini ${ }^{3}$, Slamet Mardiyanto Rahayu ${ }^{4}$, \\ Syuhriatin $^{5}$, Rosalina Edy Swandayani ${ }^{6}$, Baiq Diah Fitasari ${ }^{7}$, Diah Meidatuzzahra ${ }^{8}$ \\ Biologi, Universitas Islam Al-Azhar, Indonesia, $1,2,3,4,5,6,7,8$ \\ E-mail : hasanbasri7491@ gmail.com ${ }^{1}$
}

\begin{abstract}
Abstrak
Desa Peresak Kecamatan Narmada merupakan desa yang sangat potensial untuk ditanami tanaman seperti padi dan sayur-sayuran mengingat air yang terus mengalir sepanjang tahun. Tujuan pengabdian ini adalah untuk sosialisasi dan keterampilan kepada para petani untuk membuat pupuk organik ramah lingkungan dari bahan baku limbah rumah tangga (sayuran, buah-buahan, urin dan kotoran ternak). Pengabdian dilakukan dengan metode ceramah dan diskusi. Pada pertemuan pertama diberikan informasi dan di data jumlah kelompok tani. Pada pertemuan kedua diberi sosialisasi tentang proses pembuatan, aplikasi dan manfaat limbah rumah tangga sebagai bahan pembuatan pupuk organik cair. Kegiatan pengabdian kepada masyarakat dilaksanakan oleh tim prodi biologi dengan topik kegiatan Sosialisasi Pembuatan dan Aplikasi Pupuk Organik Cair (POC) Di Desa Peresak, Kecamatan Narmada. Kegiatan ini mendapat tanggapan yang sangat baik dari para peserta dan diskusi berjalan dengan menarik. Materi ini sangat menarik dan baru untuk mereka. Selanjutnya mereka dapat mempraktekkan di rumah untuk diaplikasikan di sawah atau dapat dijadikan sebagai peluang usaha untuk pemulihan ekonomi pada masa pandemi COVID-19.
\end{abstract}

Kata kunci: sosialisasi, limbah, pupuk organik cair

\section{Abstract}

Peresak village, Narmada sub-district, is a village with great potential for planting crops such as rice and vegetables, considering the water that continues to flow throughout the year. The purpose of this service is to disseminate knowledge and skills to farmers to make environmentally friendly organic fertilizers from household waste raw materials (vegetables, fruits, urine, and livestock manure). The service is carried out using lecture and discussion methods. At the first meeting, information, and data on the number of farmer groups were given. At the second meeting, socialization was given about the manufacturing process, application, and benefits of household waste as an ingredient for making liquid organic fertilizer. Community service activities were carried out by the Biology Study Program team with the topic of Socialization on the Manufacture and Application of Liquid Organic Fertilizer (POC) in Peresak Village, Narmada District. This activity received a very good response from the participants and the discussion was interesting. This material is very interesting and new to them. Furthermore, they can practice at home to be applied in the fields or can be used as a business opportunity for economic recovery during the COVID-19 pandemic.

Keywords: socialization, waste, liquid organic fertilizer

Copyright (c) 2021 Hasan Basri, Meilinda Pahriana Sulastri, Arista Suci Andini, Slamet Mardiyanto Rahayu, Syuhriatin, Rosalina Edy Swandayani, Baiq Diah Fitasari, Diah Meidatuzzahra

$\triangle$ Corresponding author

Address : Universitas Islam Al-Azhar

ISSN 2721-9224 (Media Cetak)

Email: hasanbasri7491@gmail.com

ISSN 2721- 9216 (Media Online)

DOI $\quad$ : https://doi.org/10.31004/abdidas.v2i6.504 
1438 Sosialisasi Pembuatan dan Aplikasi Pupuk Organik Cair (POC) di Desa Peresak Kecamatan Narmada - Hasan Basri, Meilinda Pahriana Sulastri, Arista Suci Andini, Slamet Mardiyanto Rahayu, Syuhriatin, Rosalina Edy Swandayani, Baiq Diah Fitasari, Diah Meidatuzzahra

DOI: https://doi.org/10.31004/abdidas.v2i6.504

\section{PENDAHULUAN}

Program unggulan provinsi NTB yang sedang digalakkan adalah NTB zero waste. Program ini menekankan pada model pengelolaan sampah yang memperlakukan sampah sebagai sumberdaya. Program NTB zero waste menerapkan konsep pengelolaan sampah berbasis pengurangan volume sampah, daur ulang, dan penggunaan kembali atau pengolahan sampah menjadi suatu produk yang berguna. Desa Peresak merupakan desa yang terdapat di Kecamatan Narmada sebagai penghasil padi di kabupaten Lombok Barat. Penduduk Desa Peresak sebagian besar memiliki mata pencaharian sebagai petani karena banyak warga memiliki areal persawahan sendiri yang dikelola secara mandiri. Selain sebagai petani, warga juga berprofesi sebagai peternak. Selama ini petani di desa peresak menggunakan pupuk non organik yang harganya terus meningkat dan pada situasi tertentu terjadi kelangkaan. Disisi lain penggunaan pupuk non organik secara terus menerus dapat merusak kesuburan tanah.

Menurut Riyanto dkk., (2015) penggunaan bahan kimia pertanian secara terus-menerus dapat mengurangi populasi mikroorganisme yang berperan dalam daur biogeokimia tanah, serta mengurangi ketersediaan unsur hara. Pupuk organik juga berperan sumber energi dan makanan bagi mikro dan meso fauna tanah. Dengan cukupnya tersedia bahan organik maka aktivitas organisme tanah meningkat yang juga meningkatkan ketersediaan hara, siklus hara tanah, dan pembentukan pori tanah (Hartatik dkk., 2015). Selanjutnya Kasmawan dkk., (2018) menambahkan bahwa beberapa manfaat pupuk organik bagi tanah adalah meningkatkan kesuburan tanah, memperbaiki struktur dan porositas tanah.

Ketersediaan limbah organik di desa peresak cukup melimpah yang berasal dari sampah rumah tangga, limbah ternak dan limbah pertanian. Masyarakat belum memanfaatkan secara maksimal potensi sampah organik yang ada dan belum ada upaya serius untuk mengolah dan memanfaatkannya. Padahal sampah-sampah organik tersebut masih bisa dimanfaatkan kembali untuk diolah menjadi pupuk organik.

Pupuk organik dibagi menjadi pupuk organik padat dan organik cair. Pupuk organik padat merupakan pupuk organik yang berasal dari sisa tanaman, kotoran hewan, dan kotoran manusia yang berbentuk padat sedangkan pupuk organik cair merupakan larutan yang berasal dari pembusukan bahan-bahan organik (Natsi dkk., 2016). Pupuk organik cair merupakan pupuk organik dalam bentuk cair yang dibuat menggunakan proses fermentasi oleh mikroorganisme dan menggunakan bahan ataupun sampah organik. Pemakaian pupuk organik cair relatif lebih mudah dibandingkan pupuk organik padatkarena dapat diberikan dengan penyemprotan atau penyiraman secara langsung pada tanah (Rachman dkk., 2021).

Berdasarkan potensi dan permasalahan yang dihadapi masyarakat di Desa Peresak, maka perlu dilakukan sosialisasi pembuatan Pupuk Organik Cair (POC) dari sampah organik (sayuran, buah- 
1439 Sosialisasi Pembuatan dan Aplikasi Pupuk Organik Cair (POC) di Desa Peresak Kecamatan Narmada - Hasan Basri, Meilinda Pahriana Sulastri, Arista Suci Andini, Slamet Mardiyanto Rahayu, Syuhriatin, Rosalina Edy Swandayani, Baiq Diah Fitasari, Diah Meidatuzzahra

DOI: https://doi.org/10.31004/abdidas.v2i6.504

buahan, urin dan kotoran ternak) yang banyak terdapat di desa tersebut.

\section{Permasalahan Mitra}

Identifikasi permasalahan yang di hadapi mitra sebagai berikut :

a. Kelompok petani di Desa Peresak banyak membuang sisa-sisa sampah rumah tangga, akan tetapi sampah organik (sayuran, buah-buahan, urin dan kotoran ternak) tidak dimanfaatkan.

b. Kelompok petani di Desa Peresak belum mempunyai pengetahuan dalam pembuatan pupuk organik cair dari sampah organik (sayuran, buah-buahan, urin dan kotoran ternak) .

\section{Tujuan Kegiatan}

Berdasarkan permasalahan yang telah dirumuskan di atas maka tujuan dari kegiatan ini adalah:

a. Memberikan sosialisasi dan keterampilan kepada para petani untuk membuat pupuk organik ramah lingkungan dari bahan baku limbah rumah tangga (sayuran, buahbuahan, urin dan kotoran ternak)

b. Mengingkatan pengetahuan dan kompetensi anggota kelompok tani dalam memanfaatkan limbah menjadi pupuk organik cair

\section{METODE}

Metode yang dilaksanakan dalam pengabdian yaitu: metode ceramah dan diskusi.
Pada pertemuan pertama diberikan informasi dan di data jumlah kelompok tani, selanjutnya pada pertemuan kedua diberi sosialisasi tentang proses pembuatan, aplikasi dan manfaat limbah rumah tangga dapat dimanfaatkan sebagai bahan pembuatan pupuk organik cair. Seluruh tahaptahap kegiatan pengabdian dapat dilihat dengan rincian sebagai berikut :

1. Persiapan. Tercakup dalam kegiatan ini adalah persiapan materi ceramah, pengisian daftar hadir peserta dan penyerahan makalah materi ceramah (seminar kit).

2. Pembukaan dan Sambutan-sambutan oleh Dekan Fakultas MIPA.

3. Pre-test. Setiap peserta akan diberi soal test untuk mengetahui sejauh mana pengetahuan yang dimiliki sebelum mendapat ceramah.

4. Penyampaian materi oleh narasumber. Penyuluhan atau sosialisasi dilakukan untuk memberikan pengetahuan tentang perbedaan pupuk organik cair dan anorganik, dijelaskan kandungan unsur hara pada setiap bahan atau limbah yang dijadikan untuk pembuatan pupuk organic cair, proses pembuatan pupuk organic cair dan aplikasinya, menjelaskan bahaya bagi manusia bila limbah organik maupun anorganik tidak ditangani dengan baik. Masyarakat juga diberi pengetahuan tentang jenis pupuk organic cair pase vegetatif dan generative.

5. Monitoring dan evaluasi keberhasilan pelatihan. Tahap ini dibuat untuk menilai aspek kognitif dan psikomotorik dengan menilai pemahaman dan daya serap masyarakat terhadap materi sosialisasi. 
1440 Sosialisasi Pembuatan dan Aplikasi Pupuk Organik Cair (POC) di Desa Peresak Kecamatan Narmada - Hasan Basri, Meilinda Pahriana Sulastri, Arista Suci Andini, Slamet Mardiyanto Rahayu, Syuhriatin, Rosalina Edy Swandayani, Baiq Diah Fitasari, Diah Meidatuzzahra

DOI: https://doi.org/10.31004/abdidas.v2i6.504

6. Penutup. Seluruh rangkaian acara akan ditutup oleh Dekan Fakultas MIPA Universitas Islam Alzhar, Mataram.

\section{Teknik Pengumpulan Data}

Teknik pengumpulan data dilakukan dengan observasi atau pengamatan langsung dari kegiatan yang dilakukan oleh mitra yaitu anggota kelompok tani. Observasi atau pengamatan langsung dilakukan oleh tim PKM selama kegiatan berlangsung sampai kegiatan berakhir.

\section{Teknik Analisis Data}

Analisis data dilakukan secara deskriptif dengan menggambarkan hasil yang diperoleh selama kegiatan. Selama kegiatan hasil apapun yang diperoleh di lapangan dicatat dan dilaporkan serta diceritakan dengan jelas.

\section{HASIL DAN PEMBAHASAN}

Hasil kegiatan sosialisasi pembuatan dan aplikasi pupuk organik cair (POC) untuk mewujudkan pertanian ramah lingkungan didasarkan pada respons petani sebagai pelaku pertanian sangat terarik terhadap materi pelatihan sesuai dengan sasaran dan metode sosialisasi. Capaian pelaksanaan pengabdian kepada para petani berupa sosilisasi dan pendampingan cara aplikasi, berupa sosialisasi pemanfaatan teknologi tepat guna dalam pembuatan pupuk organic cair diukur dari respons kehadiran dan diskusi yang panjang para peserta pelatihan yang dihadiri oleh 20 orang peserta.

\section{Sosialisasi Pembuatan dan Aplikasi POC}

Sosialisasi tentang pengolahan sampah organik menjadi pupuk organik cair dilakukan dalam bentuk sosialisasi berupa materi teori. Materi disampaikan oleh ketua dan dibantu oleh 3 anggota tim beserta mahasiswa. Tim sosialiasi yang lain memastikan bahwa peserta pengabdian telah faham terhadap materi yang disampaikan. Selama pemberian materi diselingi joke-joke segar dan tanya jawab agar peserta lebih semangat dan tertarik mengikuti seluruh rangkaian acara. Adapun gambar kegiatan penyampaian materi disajikan pada Gambar 1. Materi yang disampaikan berupa definisi pupuk organik cair, unsur hara yang dibutuhkan tanaman, fase vegetatif dan fase generatif pada tanaman, bahan dasar pembuatan, aplikasi yang didasarkan atas hasil penelitian yang mendukung keberhasilan penggunaan pupuk organik cair pada tanaman, dan cara pembuatannya. Adapun cara pembuatan pupuk organic cair (POC) di antaranya:

- Siapkan alat dan bahan yang digunakan dalam proses pembuatan POC

- Larutkan EM4 kedalam air secukupnya lalu tambahkan gula merah diamkan selama 20 menit

- Campurkan bahan padat seperti sayuran limbah rumah tangga, sabut kelapa, bonggol pisang dll kedalam ember/tong

- Tuangkan larutan bioaktivator atau EM4 kedalam ember/tong

- Masukkan air kencing hewan dan cucian beras kedalam ember/tong aduk hingga merata 
1441 Sosialisasi Pembuatan dan Aplikasi Pupuk Organik Cair (POC) di Desa Peresak Kecamatan Narmada - Hasan Basri, Meilinda Pahriana Sulastri, Arista Suci Andini, Slamet Mardiyanto Rahayu, Syuhriatin, Rosalina Edy Swandayani, Baiq Diah Fitasari, Diah Meidatuzzahra

DOI: https://doi.org/10.31004/abdidas.v2i6.504

- Aduk perlahan menggunakan tongkat kayu.

- Tutup rapat selama beberapa hari, lakukan pengadukan teratur hingga bau campuran tersebut seperti tape (ini menandakan fermentasi berhasil)

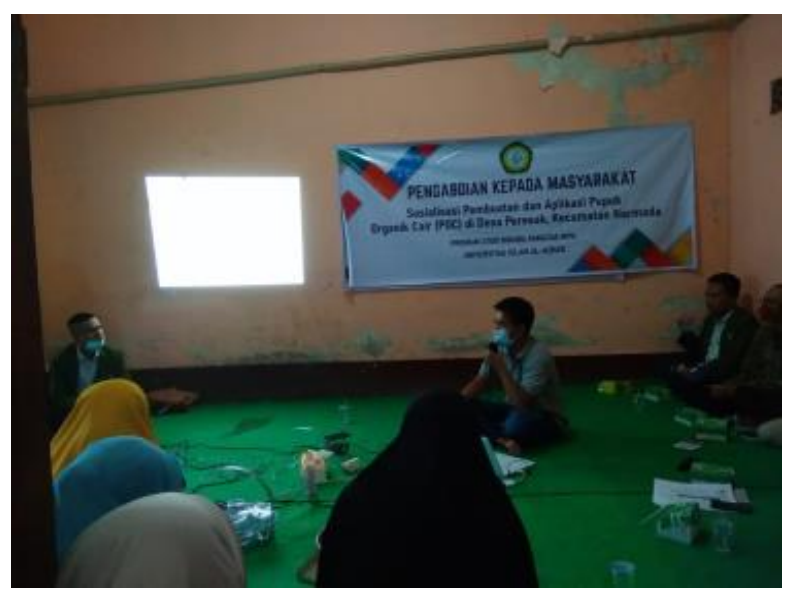

Gambar 1. Penyampaian materi

\section{Monitoring dan Evaluasi}

Untuk mengevaluasi kinerja sosialiasi ini dilakukan tanya jawab untuk memantapkan pengetahuan tentang materi yang disampaikan. Adapun hasilnya adalah bahwa para petani merasa puas mengikuti sosialisasi ini dan mereka sudah siap untuk membuat pupuk organik cair seperti yang telah diajarkan oleh tim sosialisasi. Adapun sesi tanya jawab disajikan pada Gambar 2.

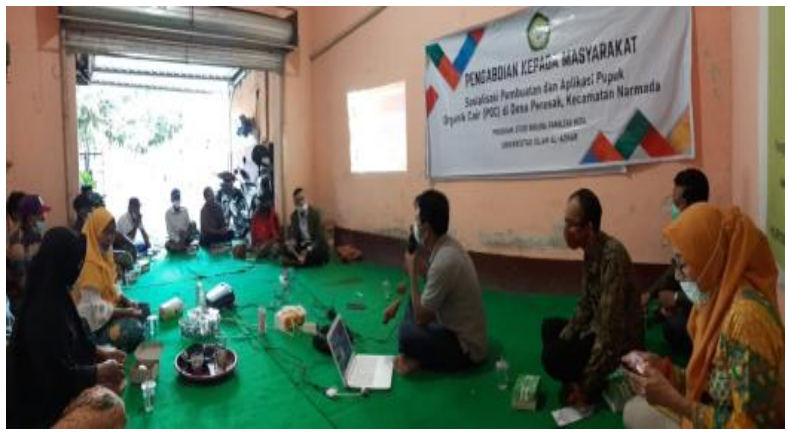

Gambar 2. Sesi Tanya Jawab

\section{Dampak dan Upaya Keberlanjutan Kegiatan}

Hasil sosialisasi yang sudah diikuti oleh peserta, mereka mendapat informasi dan pengetahuan baru tentang bagimana cara memanfaatkan sisa-sisa tanaman dan sayuran yang tidak dimanfaatkan menjadi berguna. Selama ini banyak limbah tanaman dari limbah hasil pertanian, perkebunan dan limbah sayuran yang tidak dimanfaatkan. Dengan berbekal pengetahuan dan keterampilan yang diperoleh selama sosialisasi, para peserta dapat mengolah dan memanfaatkan limbah tanaman tersebut menjadi pupuk organik cair. Hal ini dapat menjadi peluang bagi peserta untuk mengembangkan dan meningkatkan kreatifitasnya dalam memanfaatkan bahan-bahan yang ada di lingkungan sekitar yang memiliki nilai manfaat bagi kehidupan masyarakat, seperti penggunaan batang dan bonggol pisang, kulit buah-buahan, air dan sabut kelapa, dan limbah sayuran dari dapur sebagai bahan dasar pupuk cair. Hal ini merupakan salah satu solusi bagi masyarakat untuk meningkatkan kesejahteraan dan sebagai alternatif meningkatkan kandungan hara tanah yang dibutuhkan oleh tanaman selain penggunaan 
1442 Sosialisasi Pembuatan dan Aplikasi Pupuk Organik Cair (POC) di Desa Peresak Kecamatan Narmada - Hasan Basri, Meilinda Pahriana Sulastri, Arista Suci Andini, Slamet Mardiyanto Rahayu, Syuhriatin, Rosalina Edy Swandayani, Baiq Diah Fitasari, Diah Meidatuzzahra

DOI: https://doi.org/10.31004/abdidas.v2i6.504

pupuk kimia yang selama ini harga relatif meningkat.

\section{SIMPULAN}

Kegiatan pengabdian kepada masyarakat oleh tim PKM prodi biologi dengan topik kegiatan Sosialisasi Pembuatan Dan Aplikasi Pupuk Organik Cair (POC) Di Desa Peresak, Kecamatan Narmada mendapat tanggapan yang sangat baik dari para peserta. Peserta (petani) lebih leluasa berekspresi dan bertanya tentang seluk beluk pembuatan dan aplikasi pupuk organic cair. Materi ini sangat menarik dan baru untuk mereka, selanjutnya mereka dapat mempraktekkan di rumah atau setelah ini dapat dijadikan sebagai peluang usaha untuk pemulihan ekonomi pada masa pandemi COVID-19.

\section{UCAPAN TERIMA KASIH}

Penulis mengucapkan terima kasih kepada Lembaga Penelitian dan Pengabdian Masyarakat (LPPM) Universitas Islam Al-Azhar yang telah memfasilitasi kebutuhan dan kepentingan pengabdian ini, sehingga penulis dapat melaksanakan kegiatan pengabdian masyarakat ini di Desa Peresak, Kecamatan Narmada Kab. Lombok Barat.

\section{DAFTAR PUSTAKA}

Hartatik W., Husnain, Ladiyani R. Widowati. 2015. Peranan Pupuk Organik Dalam Peningkatan Produktivitas Tanah Dan Tanaman Jurnal Sumberdaya Lahan Vol. 9 No. 2, Desember 2015; 107-12.

Kasmawan I.G.A., G.N. Sutapa, I.M. Yuliara. 2018. Pembuatan Pupuk Organik
CairMenggunakan Teknologi KompostingSederhana.

BuletinUdayanaMengabdi volume17NO.02.

Natsi NA, Chaldun K., Salim. 2016 .Penerapan Teknologi Pembuatan Pupuk Organik Dalam Pengolahan Limbah Pasar Mardika Ambon. Biologi Sel. vol 5 no 1.

Rachman F, Erninda O., Maulana A , Fauzan ND , An-Najjah IS. 2021.H2 super: inovasi pupuk organik cair dari sampah pasar $\mathrm{H} 2$, Desa Sido Mukti, Kecamatan Gedung Aji Baru Alturis Journal of Community service., $\quad$ Vol 2(1):4-7 DOI:10.22219/altruis.v2i1.159621.

Rinanto, Y. Sajidan, Umi Fatmawati. 2015. Pemanfaatan Limbah Sisa Hasil Panen Petani Sayuran di Boyolali sebagai Bahan Baku Pembuatan Pupuk Cair Organik menuju Pertanian Ramah Lingkungan. Prosiding Seminar Nasional Konservasi dan Pemanfaatan Sumber Daya Alam 2015. 